\title{
Inhibitory effects of peripheral blood cells on in vitro colony formation by autologous bone marrow in aplastic anaemia: relation with response to immunosuppressive therapy
}

\author{
A BLASETTi, A FAILlE, N BALITRAND, E GLUCKMAN, A DEVERGIE, C DRESCH
}

From the Service Central de Médecine Nucleaire, Hôpital Saint-Louis, 2 Place du Docteur Fournier, 75475 Paris Cedex 10, France

SUMMARY The inhibitory activity of peripheral blood lymphocytes on autologous bone marrow was studied in 27 patients with aplastic anaemia after treatment with androgens. Inhibitory activity was hard to assess in 10 patients studied during the first year of treatment. The colony count was too low to be certain of differences between the samples incubated with or without lymphocytes. Among the 17 patients who had more than 10 colonies per $2 \times 10^{5}$ mononuclear bone marrow cells, nine showed inhibitory activity by peripheral blood lymphocytes. After 12 months of androgen therapy each of these patients showing inhibitory activity of bone marrow colony forming cells by peripheral lymphocytes responded to antithymocyte globulin. None of nine patients with few colony forming cells or no inhibitory activity of lymphocytes responded to immunosuppression.

Aplastic anaemia is not a single entity but a heterogeneous group of pancytopenias associated with bone marrow hypoplasia. The physiopathological basis of the condition remains unclear so therapeutic approaches are pragmatic. Spontaneous bone marrow recovery in some cases indicates that a residual population of stem cells may be able to repopulate the bone marrow. ${ }^{1}$ The fact that some autologous reconstitution may follow androgen therapy and also immunosuppressive therapy may indicate the existence of a population of immune cells involved in the pathogenesis of aplastic anaemia. ${ }^{2-4}$ In vitro bone marrow cultures have shown that preincubation with antithymocyte globulin (ATG) may increase granulomonocyte colony forming cells (GMCFC) and suggests the involvement of lymphocytes in the pathogenesis. ${ }^{5-7}$ Decreased colony formation by normal GM-CFC has been detected in the presence of peripheral blood cells from patients with aplastic anaemia. ${ }^{7-9}$ However these studies were performed first in an allogenic situation and the possibility of an HLA sensitisation due to multiple transfusion was suggested.1011 More recent studies have been conducted in autologous situations. ${ }^{12}$ However due to the scarcity of remaining stem cells in the early phase Accepted for publication 11 May 1982 of aplastic anaemia, these studies have to be performed after treatment for some time. We present 27 coculture studies of autologous bone marrow and lymphocytes performed two months to $10 \mathrm{yr}$ after the beginning of androgen therapy. Inhibitory activity of lymphocytes could be assessed only after one year of treatment. There was a good correlation between this activity and the response to immunosuppression.

\section{Patients and methods}

\section{PAT IENTS}

Clinical laboratory data are summarised in Tables 1 and 2 . Seventeen patients met the criteria for severe aplastic anaemia at the onset of the disease ${ }^{3}$ (platelets $<20 \times 10^{9} / 1$; reticulocytes $<20 \times 10^{9} / 1$; polymorphonuclears $\left.<2 \times 10^{9} / 1\right)$ with an "empty" bone marrow smear. The 10 remaining patients had pancytopenia with a hypocellular but not empty bone marrow smear.

Ten of the patients with severe aplasia (Table 1) were studied between two and 12 months after the onset of disease. Seventeen patients were studied one to ten years after the onset of the disease (Table 2): seven with severe aplasia (cases 11 to 17 ) and 10 with pancytopenia (cases 18 to 27 ). 
Table 1 BM-GM-CFC and \% variations with autologous peripheral blood mononuclear leucocytes $(P B M L)$ in short term follow-up patients: relation to response to immunosuppressive therapy

\begin{tabular}{|c|c|c|c|c|c|c|c|}
\hline \multirow{2}{*}{$\begin{array}{l}\text { Case No/ } \\
\text { sex/age (yr) }\end{array}$} & \multirow{2}{*}{\multicolumn{2}{|c|}{$\begin{array}{l}\text { Duration of disease before } \\
\text { study (months) and therapy }\end{array}$}} & \multirow{2}{*}{$\begin{array}{l}B M-G M-C F C \\
12 \times 105 \text { cells }\end{array}$} & \multicolumn{3}{|c|}{ Colonies in coculture/colonies in control culture } & \multirow{2}{*}{$\begin{array}{l}\text { Response to } \\
\text { immunosupressive } \\
\text { therapy }\end{array}$} \\
\hline & & & & $+P B M L$ & $\begin{array}{l}+ \text { E rosette + } \\
\text { cells }\end{array}$ & $\begin{array}{l}+ \text { E rosette - } \\
\text { cells }\end{array}$ & \\
\hline $1 \mathrm{~F} 18$ & 2 & Androgens & 3 & 1 & $0 \cdot 67$ & $1 \cdot 3$ & NT \\
\hline $2 \mathrm{~F} 22$ & 3 & Androgens & 0 & 0 & () & 0 & NR (ATG) \\
\hline $3 \mathrm{~F} 16$ & 3 & Androgens & 2 & 1 & 3 & 1 & NT \\
\hline $4 \mathrm{M} 14$ & 3 & Corticoids & $\overline{3}$ & 1.5 & - & - & NR (corticoids) \\
\hline $5 \mathrm{~F} 15$ & 4 & Androgens & () & i) & 0 & () & NT \\
\hline $6 \mathrm{M} 18$ & 4 & Androgens & 0 & 0 & 0 & 0 & NR (corticoids) \\
\hline $7 \mathrm{M} 41$ & 6 & Androgens & 9 & $1 \cdot 6$ & - & - & NR (ATG) \\
\hline $8 \mathrm{M} 21$ & 8 & Androgens & 3 & $i$ & 1 & 1.5 & NR (ATG) \\
\hline $9 \mathrm{M} 15$ & 8 & Androgens & 7 & $1 \cdot 40$ & - & - & NT \\
\hline $10 \mathrm{M} 12$ & 11 & Androgens & 5 & $0 \cdot 80$ & $1 \cdot 2$ & 1 & NR (ATG) \\
\hline
\end{tabular}

BM-GM-CFC = bone marrow granulomonocyte colony forming cells

$\mathrm{NT}=$ not tested.

NR = non-responders

ATG = antithymocyte globulin .

METHODS

\section{Rosetting procedures}

Peripheral blood mononuclear leucocytes (PBML) were obtained by Ficoll-Hypaque (Lymphoprep Nyyegaard $D=1.077 \mathrm{~g} / \mathrm{cm}^{3}$ ) separation of heparinised whole blood diluted twice with Hanks' solution (HBSS). Cells were then incubated with sheep red blood cells sensitised by 2 -aminoethylisothiouronium bromide hydrobromide (AET) (Sigma) to produce rosette formation. ${ }^{13}$ The cell suspension was then centrifuged over Ficoll-Hypaque. E rosettenegative cells were taken up from the interphase, resuspended in HBSS and washed twice in HBSS. The pellet of $E$ rosette-positive cells was processed with a hypotonic solution to disrupt the rosettes and harvest $E$ rosette-positive cells. The $E$ rosettepositive cells were then washed twice.

\section{Coculture studies}

Bone marrow cells were separated in the same way as blood cells on a Ficoll Hypaque density gradient and the supernatant cells were harvested, resuspended and washed in McCoy's $5 \mathrm{~A}$ medium. Aliquots of $6 \times$ 105 nucleated cells in $0.1 \mathrm{ml}$ were pipetted into sterile

Table 2 BM-GM-CFC and \% variations with autologous PBML in long term follow-up patients: relation to response to immunosuppressive therapy

\begin{tabular}{|c|c|c|c|c|c|c|c|}
\hline \multirow{2}{*}{$\begin{array}{l}\text { Case No/ } \\
\text { sex/age (yr) }\end{array}$} & \multirow{2}{*}{\multicolumn{2}{|c|}{$\begin{array}{l}\text { Duration of disease before } \\
\text { study (months) and therapy }\end{array}$}} & \multirow{2}{*}{$\begin{array}{l}B M-G M-C F C \\
12 \times 105 \text { cells }\end{array}$} & \multicolumn{3}{|c|}{ Colonies in coculture/colonies in control culture } & \multirow{2}{*}{$\begin{array}{l}\text { Response to } \\
\text { immunosupressive } \\
\text { therapy }\end{array}$} \\
\hline & & & & $+P B M L$ & $\begin{array}{l}+ \text { E rosette + } \\
\text { cells }\end{array}$ & $\begin{array}{l}+ \text { E rosette - } \\
\text { cells }\end{array}$ & \\
\hline \multicolumn{8}{|l|}{ Severe aplasias } \\
\hline $11 \mathrm{M} 50$ & 12 & Androgens & 21 & 0.43 & 0.77 & $0 \cdot 14$ & $\mathrm{R}$ (ATG) \\
\hline $12 \mathrm{M} 15$ & 16 & Androgens & 13 & $1 \cdot 3$ & 1 & 0.67 & NT \\
\hline $13 \mathrm{~F} 35$ & 30 & Androgens & 14 & 0.86 & 1.43 & $0 \cdot 86$ & NR (ATG) \\
\hline $14 \mathrm{M} 27$ & 36 & Androgens & 13 & 0.40 & $(0 \cdot 50$ & $0 \cdot 50$ & $\mathrm{R}(\mathrm{ATG})$ \\
\hline $15 \mathrm{~F} 54$ & 37 & Androgens & 34 & $0 \cdot 40$ & - & - & $R(A T G)$ \\
\hline $16 \mathrm{M} 31$ & 36 & Androgens & 48 & $(0 \cdot 67$ & $0 \cdot 45$ & $0 \cdot 37$ & $R(A T G)$ \\
\hline $17 \mathrm{~F} 18$ & 36 & Androgens & 10 & 1.45 & - & - & NT \\
\hline \multicolumn{8}{|l|}{ Hypoplasias } \\
\hline $18 \mathrm{M} 32$ & 12 & Androgens & 12 & $0 \cdot 36$ & 0.58 & 0.75 & $R(A T G)$ \\
\hline 19 M 23 & 12 & - & 71 & 1 & 0.61 & 0.29 & $R(A T G)$ \\
\hline $20 \mathrm{M} 21$ & 15 & Androgens & 45 & $1 \cdot 04$ & 0.98 & 0.87 & NT \\
\hline $21 \mathrm{~F} 17$ & 20 & Androgens & 18 & $0 \cdot 50$ & 0.50 & 0.11 & $R(A T G)$ \\
\hline $22 \mathrm{M} 15$ & 20 & Androgens & 23 & 2 & $1 \cdot 7$ & 4 & NT \\
\hline 23 F 39 & 22 & Androgens & 28 & $0 \cdot 82$ & 0.68 & 0.57 & $R$ (ATG) \\
\hline $24 \mathrm{M} 33$ & 22 & Androgens & 10 & 0.50 & $0 \cdot 60$ & $0 \cdot 60$ & $R$ (ATG) \\
\hline $25 \mathrm{~F} 39$ & 24 & Androgens & 10 & $0 \cdot 67$ & $1 \cdot 17$ & 1 & NT \\
\hline $26 \mathrm{~F} 51$ & 25 & Androgens & 13 & 1 & 0.92 & 0.85 & NR (ATG) \\
\hline $27 \mathrm{~F} 25$ & 120 & Androgens & 16 & 0.68 & 0.81 & $1 \cdot 22$ & NR (corticoids) \\
\hline
\end{tabular}


$8 \mathrm{~mm}$ plastic tubes with or without $6 \times 10^{5} \mathrm{PBML}$ or 6 $\times 10^{5}$ peripheral $\mathrm{E}$ rosette-positive cells or $6 \times 10^{5} \mathrm{E}$ rosette-negative cells. The cells were incubated at $37^{\circ}$ $\mathrm{C}$ for $2 \mathrm{~h}$ in $5 \% \mathrm{CO}_{2}$. The cells were then centrifuged and the whole cellular sediment was resuspended in $0.3 \%$ agar and medium containing $15 \%$ fetal calf serum and plated in triplicate $1 \mathrm{ml}$ volume with $0.1 \mathrm{ml}$ of placenta conditioned medium. ${ }^{1+}$ After 10 days of incubation at $37^{\circ} \mathrm{C}$ in a fully humidified atmosphere containing $5 \% \mathrm{CO}_{2}$, the colonies (groups containing 50 cells or more) were counted.

\section{Results}

When tested in 14 normal subjects, normal PBML peripheral $E$ rosette-positive or $E$ rosette-negative cells were not inhibitory for autologous bone marrow GM-CFC. Mean values were as follows: bone marrow + PBML $=1.02 \pm 0.22( \pm S D)$; bone marrow $+E$ rosette-positive cells $=1.05 \pm 0.29$ $( \pm S D)$; bone marrow $+E$ rosette-negative cells = $1 \cdot 02 \pm 0 \cdot 30( \pm \mathrm{SD})$ compared to bone marrow cells incubated without PBML. Lymphocytes were considered inhibitory when colonies in cocultures were less than 0.6 of control culture.

Results for aplastic patients are summarised in Tables 1, 2, and 3 .

Ten patients studied between 2 and 11 months after the onset of disease had received androgen therapy for two months or more (except case 4 who received only corticosteroids for two months). Their granulocyte count was still below $1 \times 10^{4} / 1$ and platelet count below $35 \times 10^{9} / \mathrm{l}$; bone marrow cellularity was much reduced in all of them and all needed blood support. In every case GM-CFC values were too low to allow any valid study; in the seven cases with few colonies no inhibitory activity of PBML could be seen. There was no response to immunosuppressive therapy in the six cases where this therapy was given (two cases with no colony growth and four cases with rare colonies).

All the 17 patients studied more than one year after the onset of the disease had received androgen therapy, except case 19 who had post-hepatitic aplastic anaemia. All had more than 10 colonies $2 \times$ $10^{5}$ bone marrow mononuclear cells; cases $16,19,20$ were in the normal range. No correlation was found between the number of colonies and the severity of the disease at onset or the clinical data at the time of the study. Four of seven aplasias and 5/10 hypoplasias had suppressor cells. Inhibitory activity was found in both $E$ rosette-positive and $E$ rosette-negative cells; however in three cases $E$ rosette-negative cells were much more inhibitory than $E$ rosette-positive cells (cases 11, 19, 21).

Immunosuppressive therapy was given in 11 cases using ATG and in one case using corticosteriods. All nine patients who displayed inhibitory activity responded well (cases $11,14,15,16,18,19,21,23,24$ ) with an increase in granulocytes $>1 \times 10^{4} / \mathrm{l}$ and no further requirement for blood support within a month of immunosuppression. Among the eight patients without inhibitory activity at the time of the study, three received immunosuppressive therapy and failed to respond (case 13, 26, 27).

\section{Discussion}

Reports of bone marrow recovery after unsuccessful allogeneic bone marrow graft or after treatment with high doses of cyclophosphamide or ATG ${ }^{15}$ it suggest that an immunological mechanism is involved in some cases of aplastic anaemia. Therefore it is important to try to identify patients who might benefit from immunosuppressive therapy. Coculture studies in an autologous system are impossible to perform at the onset of the disease due to the scarcity of the remaining bone marrow cells. Coculture studies in an allogeneic system have been criticised on the grounds that inhibition could be related to transfusion. ${ }^{10} 11$ Our results show that it is useless to try, by autologous coculture, to identify patients who might benefit from immunosuppression at an early stage of the disease. On the one hand results of coculture are unreliable when the number of colonies is too low; on the other hand none of the six patients treated in the first year of the study responded to immunosuppression.

If one supposes that stem cell failure may be

Table 3 Coculture results: relation to response to immunosuppressive therapy

\begin{tabular}{|c|c|c|c|}
\hline \multirow[t]{2}{*}{ Patients } & \multirow{2}{*}{$\begin{array}{l}\text { Invitro } \\
\text { inhibition }\end{array}$} & \multicolumn{2}{|c|}{ Immunosuppressive therapy } \\
\hline & & Patients tested & Response \\
\hline $\begin{array}{l}\text { Short term follow up } \\
\text { patients }=10 \\
\text { Long term follow up } \\
\text { patients }=17\end{array}$ & $\begin{array}{l}\text { No growth } 3 \\
\text { No inhibition } 7 \\
\text { Inhibition } 9 \\
\text { No inhibition } 8\end{array}$ & $\begin{array}{l}2 \\
4 \\
9 \\
3 \\
5 \text { (not tested) }\end{array}$ & $\begin{array}{l}2 \text { non-responders } \\
4 \text { non-responders } \\
9 \text { responders } \\
3 \text { non-responders }\end{array}$ \\
\hline
\end{tabular}


accompanied in some cases by a dysfunction of the immune system, evidence of this dysfunction could only be obtained after several months of androgentherapy, when this treatment has allowed multiplication of the remaining stem cells. Our results show that a treatment of at least 12 months is necessary to increase the CFC concentration to levels permitting valuable coculture studies.

After one year or more of androgen-therapy autologous coculture showed a residual autoimmune process in half the patients studied. As in other studies $^{12}$ we did not find in most cases a predominance of inhibiting activity in the $E$ rosette-positive lymphocyte population. This could be due to the fact that the suppressor activity is shared by subpopulations of cells present in both E-positive and E-negative cells or by monocyte-macrophages, which would be present in the E-negative cells, as suggested by Suda. ${ }^{17}$ Recent studies of normal subjects seem to indicate that a subset of null lymphocytes may normally be inhibitory against bone marrow GMCFC. ${ }^{18}$ Bacigalupo and coworkers ${ }^{19}$ found that $E$ rosette-positive bone marrow cells are not normally inhibitory, but may become so if previously activated by pokeweed mitogen. PHA and Con-A have also been shown to be capable of inducing suppressor activity in T lymphocytes. ${ }^{20}$ Thus the term "autoimmune inhibition" in aplastic anaemia may be incorrect and it would be more appropriate to speak of "dysfunction" of the lymphocyte and monocyte populations that normally control haematopoiesis.

It appears that lymphomonocyte dysfunction persists in about half of the patients with prolonged aplasia. Coculture inhibition of GM-CFC in these cases correlated with their responsiveness to immunosuppressive therapy. Further study of the links between immune cells and haematopoietic stem cells in pancytopenias would therefore seem to be worthwhile in defining new approaches to treatment.

\section{References}

' Speck B, Cornu P, Jeannet M, et al. Autologous bone marrow recovery following allogeneic bone marrow transplantation in a patient with severe aplastic anaemia. Exp Hematol 1976;4:1317.

2 Jeannet M, Speck B, Rubinstein A, Pelet B, Wyss M, Kummer H. Autologous marrow reconstitution in severe aplastic anaemia after ALG pretreatment and HLA semicompatible bone marrow cell transfusion. Acta Hematol 1976;55:129-39.

${ }^{3}$ Gluckmann E, Devergie A, Faille A, et al. Treatment of severe aplastic anaemia with antilymphocyte globulin. Exp Hematol 1978;6:679-87.
${ }^{4}$ Baran DT, Griner PF, Klemperer MR. Recovery from aplastic anaemia after treatment with cyclophosphamide. $N$ Engl J Med 1976;295:1522-9.

${ }^{5}$ Faille A, Barrett AJ, Balitrand N, Ketels F, Gluckmann E, Najean Y. Effect of antilymphocyte globulin on granulocyte precursors in aplastic anaemia. Br J Haematol 1979;42:371-80.

- Ascensao JA, Pahwa R, Kagan W, Hansen JA, Moore MAS, Good RA. Aplastic anaemia: evidence for an immunological mechanism. Lancet 1976;i:669-71.

${ }^{7}$ Kagan WA, Ascensao JA, Pahwar N. et al. Aplastic anaemia: presence in human bone marrow of cells that suppress myelopoiesis. Proc Natl Acad Sci USA 1976;73:2890-4.

8 Singer JW, Brown JE, James MC, et al. Effect of peripheral blood lymphocytes from patients with aplastic anaemia on granulocytes colony growth from HLA matched and mismatched marrows: effect of transfusion sensitisation. Blood 1978;52:3746.

${ }^{9}$ Hoffman R, Zanjani ED, Lutton JD, Zalusky R, Wasserman LR. Suppression of erythroid colony formation by lymphocytes from patients with anemia. N Engl J Med 1977;296:19-27.

${ }^{10}$ Singer JW, Doney KC, Thomas ED. Coculture studies of 16 untransfused patients with aplastic anaemia. Blood 1979;54:180-5.

1 Torök-Storb BJ, Sieff C, Storb R, Adamson J, Thomas ED. In vitro tests for distinguishing possible immune mediated aplastic anemia from transfusion induced sensitization. Blood 1980;55:211-5.

12 Nissen C, Cornu P, Gratwohl A, Speck B. Peripheral blood cells from patients with aplastic anaemia in partial remission suppress growth of their own bone marrow precursors in culture. $\mathrm{Br} \mathrm{J}$ Haematol 1980;45:233-43.

13 Hockland P, Hockland M, Heron I. An improved technique for obtaining $E$ rosettes with human lymphocytes and its use for B cell purification. J Immunol Methods 1976;13:175-80.

14 Pike B, Robinson WA. Human bone-marrow growth in agar gel. $J$ Cell Phys 1970;76:78-80.

15 Territo MC. For the UCLA bone-marrow transplantation team. Autologous bone-marrow repopulation following high dose cyclophosphamide and allogeneic marrow transplantation in aplastic anaemia. Br J Haematol 1977;36:305-12.

16 Thomas ED, Storb R, Giblett ER, et al. Recovery from aplastic anaemia following attempted bone-marrow transplantation. Exp Hematol 1976;4:97-102.

${ }^{17}$ Suda T, Misoguchi H, Miura Y, Kubota K, Takaku F. Enhancement of granulocytic colony formation by deletion of phagocytic cells in the bone-marrow of patients with idiopathic aplastic anaemia. Exp Hematol 1980;8:659-64.

${ }^{18}$ Morris TCM, Vincent PC, Sutherland R, Hersey P. Inhibition of normal human granulopoiesis in vitro by non $B$ non $T$ lymphocytes. Br J Haematol 1980;45:541-50.

19 Bacigalupo A, Podesta M, Mingari MC, et al. Generation of CFU-C suppressor T cells in vitro. An experimental model for immune mediated marrow failure. Blood 1981;57:491-6.

${ }^{20}$ Banisadre, Ascensao JL, Kay NE, Ash RC, Zanjani ED. PHA induced suppression of human blood BFU-E is mediated by $T$ cells. Exp Hematol 1980;8 (suppl 7):44 (Abstract).

Requests for reprints to: Dr A Faille, Service du Professeur Y Najean INSERM U 204, Centre Hayem, Hôpital SaintLouis, 75475 Paris Cedex 10, France. 